\title{
Waterbirds (other than Laridae) nesting in the middle section of Laguna Cuyutlán, Colima, México
}

\author{
Eric Mellink ${ }^{1} \&$ Mónica E. Riojas-López ${ }^{2}$ \\ 1 Departamento de Biología de la Conservación, División de Biología Experimental y Aplicada, Centro de Investigación \\ Científica y de Educación Superior de Ensenada, Baja California. CICESE, P. O. Box 434844, San Diego, California \\ 92143-4844; emellink@cicese.mx \\ 2 Departamento de Ecología, Centro Universitario de Ciencias Biológicas y Agropecuarias, Universidad de Guadalajara, \\ Km 15.5 carr. Nogales, 45100 Zapopan, Jalisco, México; meriojas@cucba.udg.mx
}

\author{
Received 18-X-2006. Corrected 07-IV-2007. Accepted 27-VII-2007.
}

\begin{abstract}
Laguna de Cuyutlán, in the state of Colima, Mexico, is the only large coastal wetland in a span of roughly $1150 \mathrm{~km}$. Despite this, the study of its birds has been largely neglected. Between 2003 and 2006 we assessed the waterbirds nesting in the middle portion of Laguna Cuyutlán, a large tropical coastal lagoon, through field visits. We documented the nesting of 15 species of non-Laridae waterbirds: Neotropic Cormorant (Phalacrocorax brasilianus), Tricolored Egret (Egretta tricolor), Snowy Egret (Egretta thula), Little Blue Heron (Egretta caerulea), Great Egret (Ardea alba), Cattle Egret (Bubulcus ibis), Black-crowned Nightheron (Nycticorax nycticorax), Yellow-crowned Night-heron (Nyctanassa violacea), Green Heron (Butorides virescens), Roseate Spoonbill (Platalea ajaja), White Ibis (Eudocimus albus), Black-bellied Whistling-duck (Dendrocygna autumnalis), Clapper Rail (Rallus longirostris), Snowy Plover (Charadrius alexandrinus), and Black-necked Stilt (Himantopus mexicanus). These add to six species of Laridae known to nest in that area: Laughing Gulls (Larus atricilla), Royal Terns (Thalasseus maximus), Gull-billed Terns (Gelochelidon nilotica), Forster's Terns (S. forsteri), Least Terns (Sternula antillarum), and Black Skimmer (Rynchops niger), and to at least 57 species using it during the non-breeding season. With such bird assemblages, Laguna Cuyutlán is an important site for waterbirds, which should be given conservation status. Rev. Biol. Trop. 56 (1): 391-397. Epub 2008 March 31.
\end{abstract}

Key words: Tropical coastal lagoon, breeding, conservation, mangrove, Phalacrocoracidae, Ciconiiformes, Charadriiformes.

Along the Pacific coast of Mexico, between Marismas Nacionales, Nayarit, and the center of the state of Guerrero, a span of roughly 1150 $\mathrm{km}$, there is only one large coastal wetland: Laguna de Cuyutlán, in the state of Colima. This is a large wetland, $35 \mathrm{~km}$ long, $6 \mathrm{~km}$ wide at it widest, in which water depth diminishes and salinity rises from west to east, although occasional entrance of fresh water from the Río Armería lowers salinity at its eastern end (Instituto Oceanográfico de Manzanillo 1984). Vegetation around the lagoon is mostly of mangroves (Rhizophora mangle Linnaeus, 1753 and Laguncularia racemosa (L.) Gaertn, f.) and tule (Typha domingensis Persoon 1807), while saltwort (Batis maritima Linnaeus, 1759), pickleweed (Salicornia Linnaeus 1753), saltgrass (Distichlis spicata (L.) Greene 1887) and saltbush (Atriplex Linnaeus 1753) occur at the edge of the lagoon and in vegetated patches in shallow spots within it. The western section is connected to the sea through two artificial channels and by a tunnel under the city of Manzanillo. A levee was built early in the $20^{\text {th }}$ century to manage water levels to benefit salt works in the eastern part of the lagoon (Luna 1987), and several smaller, artisanal structures protect salt ponds west of it. 
The importance of the lagoon for breeding waterbirds is little known, although this lagoon and some small associated wetlands account for approximately $90 \%$ of the estuarine surface of the state of Colima. Indeed, the lagoon was largely excluded even from Edwards' (1968, 1976, 1985) and Howell's (1999) guides to bird finding in Mexico. The birds of Colima have been the subject of only one published research (Schaldach 1963, 1969) that did not report the waterbirds of the Laguna Cuyutlán in detail. On his single visit to the lagoon, on 14 May 1959, Schaldach (1963) visited some shores and an island (now known locally as Islote Panteones), south of the town of Colomos in the western section. He reported the nesting of hundreds of [Neotropic] Cormorants (Phalacrocorax brasilianus (J. F. Gmelin 1789)), 100+ Little Blue Egrett (Egretta caerulea (Linnaeus 1758)), 100+ Great Egret (Ardea alba Linnaeus 1758), some Snowy Egrets ( $E$. thula (Molina 1782)), and the apparent nesting of some Tricolored Herons (E. tricolor (Muller 1776)) on this island.

Through a series of aerial surveys, Knoder et al. (1980) documented some breeding waterbirds in Mexico. In Laguna Cuyutlán they counted 30 nests of Great Egret on 20 January 1977, and 8000 nests of [Neotropic] Cormorants on 24 May 1978. They indicated that 10000 Laughing Gulls (Larus atricilla Linnaeus, 1758) in addition to "frigatebirds" (number not stated) nested in the lagoon in 1978. On 20 January 1977 they counted 500 nests of Magnificent Frigatebird (Fregata magnificens Mathews 1914) near the Manzanillo airport (west of Laguna Cuyutlán), but did not mention any in the lagoon itself.

Howell and Webb's book (1995) was based on extensive fieldwork throughout Mexico, but its scope allows for information on specific sites only in some cases. They precisely indicate four species of waterbirds nesting in Laguna de Cuyutlán: Magnificent Frigatebird, Clapper/King Rail (either part of Rallus longirostris Boddaert 1783, or of $R$. elegans Audubon 1834), Laughing Gull, and Black
Skimmer (Rynchops niger Linnaeus 1758). Their maps have Laguna Cuyutlán inside the breeding distributions of 30 additional species of waterbirds, all non-laridae. A previous work on birds of Colima by Howell (1994) did not include this lagoon.

Snowy Plovers (Charadrius alexandrinus Linnaeus 1758), Royal Terns (Thalasseus maximus (Boddaert 1783), Gull-billed Terns (Gelochelidon nilotica (J. F. Gmelin 1789)), Forster's Terns (Sterna forsteri Nuttall 1834), and Least Terns (Sternula antillarum (Lesson 1847)) have recently been documented breeding in the middle section of Laguna Cuyutlán (Mellink and Riojas 2005, 2006, Mellink et al. 2007, Palacios and Mellink 2007). The nonbreeding waterbirds of the lagoon were recently assessed by Mellink and de la Riva (2005).

We recorded the waterbirds breeding in the middle portion of Laguna Cuyutlán between 2003 and 2006. In this contribution we report on the waterbirds, other than Laridae, that nest in that area.

\section{MATERIALS AND METHODS}

The central part of Laguna Cuyutlán consists of very shallow waters (mostly less than $30 \mathrm{~cm}$ deep) dotted with low islets covered by saltwort and pickleweed and bare patches, but some with scattered small mangrove shrubs as well. On three such islets we found breeding non-laridae waterbirds: Islets 26-59 $\left(19^{\circ} 00^{\prime} 26^{\prime \prime} \mathrm{N}, 104^{\circ} 11^{\prime} 59^{\prime \prime} \mathrm{W}\right)$, 28-00 (19 $\left.00^{\prime} 28^{\prime \prime} \mathrm{N}, 104^{\circ} 11^{\prime} 00^{\prime \prime} \mathrm{W}\right)$, and 29-36 $\left(19^{\circ} 00^{\prime} 29^{\prime \prime} \mathrm{N}, 104^{\circ} 10^{\prime} 36^{\prime \prime} \mathrm{W}\right)$. Towards the middle of the Lagoon there is a rocky islet known as

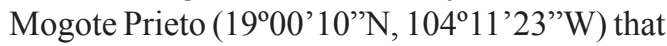
is bordered by a narrow mangrove fringe, has a narrow belt of tropical deciduous forest, and an area with pitayo cimarrón (Stenocereus sp.) in the center. It has a small mangrove detachment $20 \mathrm{~m}$ to the north of it, which we called Mogote Chico (1900'17" N, 104'11'22"W). On both Mogote Prieto and Mogote Chico we recorded nesting waterbirds. 
We visited the area on 20 May 2003, 12 May 2004 (very briefly on both occasions), 23 April, 14-15 May, 3 June, 2-3 July 2005, and 5 January 2006. We did our surveys aboard a 3-m long, flat-bottomed skiff propelled by pole and, when water depth allowed it, oar, guided by Jorge Luis Ramírez, a local artisanal fisherman. We usually departed and landed at a small, hand-made pier (Cotorra's Landing; $19^{\circ} 00^{\prime} 48^{\prime \prime} \mathrm{N}, 104^{\circ} 11^{\prime} 22^{\prime}$ 'W). In May 2004 we documented breeding activity by waterbirds on abandoned saltpans adjacent to Salina San Buenaventura (19 $\left.00^{\circ} 57^{\prime} \mathrm{N}, 104^{\circ} 10^{\prime} 44^{\prime \prime} \mathrm{W}\right)$ by the shore of middle section of the lagoon. On 3 July 2005 from a distance we briefly examined the southern half of Islote Panteones.

We searched for a minimal confirmation of nesting for all species that appeared to do so, but we did not try to get precise counts, especially of Ciconiiformes, as they fly off their nests easily, and we tried to reduce the amount of time of our disturbance on the waterbirds. Also, when they nest inside the mangroves the nests are often detected only as the adults flee, but many flee before they can be sighted.

\section{RESULTS}

\section{Neotropic Cormorant (Phalacrocorax} brasilianus): On 23 April 2005 this species was very abundant among the canopy of the mangrove and tropical forest of Mogote Prieto, and one individual flew in carrying nest material. On 3 June 2005 there were a few hundreds of nests in the canopy of all three arboreal plant communities at Mogote Prieto, and some tens at Mogote Chico. Most nests that we could see contained two chicks. One adult regurgitated a $214 \mathrm{~mm}$ (total length) mullet (Mugil cephalus Linnaeus 1758). On 2 July 2005 there were several hundreds of individuals, mostly fledglings at both Mogotes, although there were still a few 1/4-grown chicks. Overall we observed some thousands of comorants that were nesting, or carrying nest materials and food. Since we surveyed a small portion of the lagoon and mangroves, the nesting substrate of the cormorants, are widespread, our observations appear to be concordant with numbers reported by Knoder et al. (1980).

Tricolored Egret (Egretta tricolor): On 20 May 2003 there were many nests of this species at Mogote Prieto, but we didn't count nor examine them. On Mogote Chico there was one adult on a nest. On 23 April 2005 there were several tens of individuals among the mangrove canopy of Mogote Prieto. Some had complete nuptial plumes, but nuptial plumes of other individuals were still $1 / 4$ of their growth. On 3 June 2005 we saw one nest with three small chicks ( $1 / 4$ growth), one with two halfgrown chicks, and four half-grown chicks walking on the mangrove branches, at Mogote Chico. There were notably fewer adults than in May, suggesting that most had finished their breeding attempt, either successful or not. On 2 July 2005 there were at least 100 fledglings at both Mogotes. On 3 July 2005 we observed one Tricolored Heron at Islote Panteones.

Snowy Egret (Egretta thula): There were several individuals nesting at Mogote Prieto on 20 May 2003. On 23 April 2005 there were tens of adult birds among the canopy of the vegetation on Mogote Prieto, and on 3 June 2005 there were about 20 nests at this site. On this date there were 2 small and two half-grown chicks of this species at Mogote Chico. On 2 July 2005 we saw several large chicks of this species among the mangroves of both Mogotes.

Little Blue Heron (Egretta caerulea): On 3 June 2005 we found six adults on nests among the branches of pitayo cimarrón on Mogote Prieto. One of the nests contained at least three eggs. On 2 July 2005 we observed one half-grown chick in a different nest in that area. On 3 July 2005 we observed five Little Blue Egrets at Islote Panteones.

Great Egret (Ardea alba): This species is a common breeder throughout western Mexico. 
On 3 June 2005 there were about 20 nests on Mogote Prieto, one of which we found to contain eggs. On 3 July 2005 we observed 14 Great Egrets at Islote Panteones.

Cattle Egret (Bubulcus ibis (Linnaeus 1758)): There were some nests of this species at Mogote Prieto on 20 May 2003. On 2 July 2005 we saw a few hundreds of nests of it. We examined several, and one contained 1 egg, five contained 2 eggs, one contained 1 egg and one half-grown chick, and one contained 3 half-grown chicks.

Black-crowned Night-heron (Nycticorax nycticorax (Linnaeus, 1758)): On 23 April 2005 one adult flew out of the mangroves suspiciously at Mogote Prieto. On 3 June 2005 there were some tens of adults sitting on nests at Mogote Prieto. On this date, about a dozen were on nests at Mogote Chico. The nests contained from small chicks to juveniles. We observed 14 individuals on top of mangroves at Mogote Prieto on 2 July 2005, 6 or 7 of which were juveniles. We counted 5 additional juveniles among the mangroves.

Yellow-crowned Night-heron (Nyctanassa violacea (Linnaeus, 1758)): One adult flew out the mangrove at Mogote Prieto and several were on nests at Mogote Chico on 20 May 2003. We did not see the species in 2005.

Green Heron (Butorides virescens (Linnaeus, 1758)): On 3 June 2005 we found one nest with two eggs in a small mangrove shrub on islet 29-36, and five adults flying out of the mangrove at Mogote Chico.

Roseate Spoonbill (Platalea ajaja (Linnaeus, 1758)): About 15 adults were on nests at Mogote Chico on 20 May 2003. There were two, at least, in the canopy of Mogote Prieto on 23 April 2005. On 3 and 4 June 2005 there were 10-15 adults on nests at Mogote Prieto, of which two nests contained 2 eggs, one, 3 eggs, and one, 4 eggs. On 2 July 2005 we estimated that probably $40-50$ nests of this species existed on Mogote Prieto and Mogote Chico. We examined 9 such nests: one nest contained at least 1 chick; one nest, 2 chicks +2 eggs; three nests, 2 chicks; two nests, 3 chicks; and two nests, 4 chicks. Except the 2 chicks of one nest that were $3 / 4$-grown, all chicks were $1 / 4$-grown.

Despite their visibility from the surface and from the air, Roseate Spoonbills were not recorded breeding at Laguna Cuyutlán by Schaldach (1963) or by Knoder (1980), nor was Laguna Cuyutlán included in the breeding distribution of Roseate Spoonbills by Howell and Webb (1995). Indeed, reportedly Roseate Spoonbills were very rare 25 years ago, and they have increased slowly since then (Jorge Luis Ramírez pers. comm.).

White Ibis (Eudocimus albus (Linnaeus, 1758)): One juvenile was standing on the ground by Mogote Prieto on 20 May 2003. On 23 April 2005, one adult flew out of the mangrove canopy of Mogote Prieto, and one flew in carrying nest material. On 3 June 2005, there were at least about 20 nests, possibly more, on the south side of Mogote Prieto. These included one nest with 1 egg, five nests with 2 eggs, and three nests with 3 eggs. On 2 July 2005 we saw at least 20 adults, and one fledgling among mangroves on Mogote Prieto.

Black-bellied Whistling-duck (Dendrocygna autumnalis (Linnaeus, 1758)): On 3 June 2005 we saw two adults on islet 29-36 and several on both Mogotes, but could find no evidence of their nesting. On 2 July 2005, 6 flew from the middle of Mogote Prieto, but we did not inspect the area to try to find nests. They are locally reported to nest later in the year (Jorge Luis Ramírez pers. comm.), which is concordant with the species' biology elsewhere (Leopold 1959), although in mid-June a worker at a tilapia farm a couple of kilometers south of San Buenaventura reportedly saw a large clutch of chicks of this species (Jorge Luis Ramírez pers. comm.). 
Clapper Rail (Rallus longirostris): Laguna Cuyutlán is within the distribution of this species, as recognized by the AOU (1998). However, Howell (1994) and Howell and Webb (1995) indicated that local birds could be King Rail ( $R$. elegans) rather than Clapper Rail. In 2003 and 2004 we heard this rail calling from within the marshy vegetation near Cotorra's Landing. On 23 April 2005 we saw one foraging in the mud a few meters from vegetation at the same place. On 3 June 2005 we saw one foraging in the mud on an islet in front of the landing, at 10:00 (summer saving time), and three foraging in the mud, independent from each other, near the landing, at about 17:00. On 15 May 2005 two different fishermen at Embarcadero Tepalcates, in western Laguna Cuyutlán, clearly recognized the species in a card depicting different waterbirds, and indicated that they were common in the marsh. We have not found evidence of nesting, nor had any of our informants seen such, but Howell and Webb report it specifically as nesting at Cuyutlán. It cannot be else, as this species is a sedentary resident. It is surprising that Schaldach (1963) did not record King (or Clapper) Rail in Laguna Cuyutlán, but we believe that this could be more due to his surveying scheme rather than due to the absence of the species at that time.

Snowy Plover (Charadrius alexandrinus): On 11 May 2004 we found four pairs of Snowy Plovers in an area of $50 \times 50 \mathrm{~m}$ of abandoned salt pans adjacent to Salina San Buenaventura, and the three-egg nest of one of them (Mellink and Riojas-López 2005). We also found a chick outside this $50 \times 50 \mathrm{~m}$ plot.

Black-necked Stilt (Himantopus mexicanus (Muller, 1776)): On 20 May 2003 several individuals performed distractive behavior, near the muddy islets, but we could not locate any nest. On 12 May 2004, we saw more adults performing distractive behavior in the area, and we located a nest with 4 eggs on islet 26-59. On 23 April 2005 there was a nest with 3 eggs near Cotorra's Landing; on 14 May 2005 three nests with 4 eggs each at islet 28-00, and these nests had still eggs on 3 June 2005. On 23 May 2005 they were nesting throughout the entire area, and one nest we examined on islet 29-36 contained 4 eggs. On 3 June there were three nests with 4 eggs each and one nest with 3 eggs on islet 28-00, and 4 June 2005 we documented seven adults sitting on nests on different islets, three of which contained 3, 4, and 4 eggs. On 2 July 2005 we tried to find chicks of this species but were unsuccessful. Other nests had been drowned by the increase in water level (about $30 \mathrm{~cm}$ higher than in June) that resulted from the Spring tides of 22-23 June. We don't know the fate of any of those nests.

We were unable to find chicks, while several of the same nests remained in use throughout our study. Chicks are very precocial and are able to hide away from their nests almost since birth (Robinson et al. 1999). Also, nests are frequently re-used (Robinson et al. 1999). The lengthy season through which we found eggs, compared to the known incubation period (21-24 days) suggested that several clutches might have been produced in the area. Indeed two nests that had contained eggs in June still contained eggs in July. This is concordant with the fact that we commonly found many more adults performing distractive behavior than those that could be accounted for by the number of nests.

\section{DISCUSSION}

In addition to the species we have detected nesting in this part of Laguna Cuyutlán, Magnificent Frigatebirds have been reported as breeders in the lagoon, but neither we nor our boater have seen evidence of it in the area we studied. This species is commonly present during the summer on Mogote Prieto and Mogote Chico, and on 2 July 2005 we counted 60 of them on the latter, about half of which were adult males, and half juveniles, but there was not a single female. Although the mangrove here seems suitable for their nesting, lack of gulls and terns to cleptoparasitize in late 
Winter and early Spring could explain their absence at this time and, hence, their non-nesting. Anhingas (Anhinga anhinga (Linnaeus, 1766)) and Boat-billled Herons (Cochlearius cochelarius (Linnaeus, 1766)), typical of estuarine systems in southern Mexico, might require fresher water than that of Laguna Cuyutlán (Mellink et al. 1998).

All the species breeding in Laguna Cuyutlán are common along the west coast of tropical Mexico and all but the Clapper Rail are considered by the Mexican government as not having conservation problems. Although most species are not considered threatened by the Mexican government, with at least 21 species of waterbirds nesting in the lagoon, and at least 57 species using it during the nonbreeding season, Laguna Cuyutlán appears as very important for waterbirds, especially when compared with other estuarine systems along the southern part of Mexico's Pacific coast ( Mellink et al. 1998, Cupul-Magaña 2000, Hernández-Vázquez and Mellink 2001). The role of Laguna Cuyutlán for waterbirds is enhanced by it being the only large wetland in a very large span of coast.

Surveying efforts of waterbirds in Laguna Cuyutlán have been so far insufficient. Data are too scant to allow for speculation on changes of the species' local populations through time. Further and more detailed prospecting and monitoring should be of great value in assessing the complete value of this area for waterbirds and in providing information to understand the ecology of the species nesting locally. Despite the paucity in information, we are convinced that the data available are sufficient to recommend that the area be given official conservation status and biological recognition.

\section{ACKNOWLEDGMENTS}

In 2003 and 2005 our fieldwork in Laguna Cuyutlán benefited collaterally from a grant from the U.S. Fish and Wildlife Service to E. Palacios and E. Mellink, administered by PRONATURA-Mar de Cortés (La Paz office).
In 2004 and 2006, field work was financed by the Centro de Investigación Científica y de Educación Superior de Ensenada and the Universidad de Guadalajara. Jorge Luis Ramírez, Jorge Luis Ramírez Jr., Jaime Luévano, and Eduardo Palacios provided logistic support. Mollie Harker confirmed the taxonomic identity of some aquatic plants. Two anonymous reviewers helped to improve the article. We extend our greatest appreciation to all of them.

\section{RESUMEN}

Durante la prospección de la parte media de la Laguna Cuyutlán, una gran laguna costera en Colima, México, entre 2003 y 2006, documentamos la anidación de 15 especies de aves acuáticas que no pertenecer a la familia Laridae: Phalacrocorax brasilianus, Egretta tricolor, Egretta thula, Egretta caerulea, Ardea alba, Bubulcus ibis, Nycticorax nycticorax, Nyctanassa violacea, Butorides virescens, Platalea ajaja, Eudocimus albus, Dendrocygna autumnalis, Rallus longirostris, Charadrius alexandrinus e Himantopus mexicanus. Estas se suman a seis especies de Laridae que anidan en esta parte de la laguna: Larus atricilla, Thalasseus maximus, Gelochelidon nilotica, Sterna forsteri, Sternula antillarum y Rynchops niger, y a cuando menos 57 especies de aves acuáticas que la usan durante la época no reproductiva. Con estas comunidades ornitológicas, la Laguna Cuyutlán es un sitio importante para las aves acuáticas, que debería recibir estatus de protección.

Palabras clave: Laguna costera tropical, anidación, conservación, manglares, Phalacrocoracidae, Ciconiiformes, Charadriiformes.

\section{REFERENCES}

American Ornithologists' Union (AOU). 1998. Checklist of North American birds. AOU, Washington D.C., USA.

Cupul-Magaña, F.G. 2000. Nota sobre la avifauna acuática de las islas y los humedales costeros de Bahía Banderas, Jalisco-Nayarit, México. Mexicoa 2:85-92.

Edwards, E.P. 1968. Finding birds in Mexico. Sweet Briar, Virginia, USA.

Edwards, E.P. 1976. Supplement to finding birds in Mexico. Sweet Briar, Virginia, USA. 
Edwards, E.P. 1985. Supplement to finding birds in Mexico. Sweet Briar, Virginia, USA.

Hernández-Vázquez, S., \& E. Mellink. 2001. Coastal waterbirds of El Chorro and Majahuas, Jalisco, México, during the non-breeding season, 1995-1996. Rev. Biol. Trop. 49:359-367.

Howell, S. N. G. 1994. Additional information on the birds of Colima and adjacent Jalisco, Mexico. Euphonia $3: 33-54$.

Howell, S.N.G. 1999. A bird-finding guide to Mexico. Cornell, Ithaca, New York, USA.

Howell, S.N.G., \& S. Webb. 1995. A guide to the birds of Mexico and northern Central America. Oxford, New York, New York, USA.

Instituto Oceanográfico de Manzanillo. 1984. Evaluación de los recursos ecológicos del estado de Colima. Colima, México.

Knoder, C.E., P.D. Plaza \& A. Sprunt IV. 1980. Status and distribution of the Jabiru Stork and other water birds in western Mexico, p. 58-127. In P.P. Schaeffer \& S.M. Ehlers, (eds.). Proceedings of the National Audubon Society's Symposium on the Birds of Mexico; their ecology and conservation. Western Education Center, Tiburon, California, USA.

Luna, J.R. 1987. Rehabilitación de la Laguna de Cuyutlán, Colima. Resúmenes del Congreso Nacional de Oceanografía de México 7:265.

Leopold, A.S. 1959. Wildlife of Mexico. University of California, Berkeley, California, USA.
Mellink, E. \& G. de la Riva. 2005. Non-breeding waterbirds at Laguna de Cuyutlán and associated wetlands, Colima, Mexico. J. Field Ornithol. 76: 158-167.

Mellink, E. \& M.E. Riojas-López. 2005. New breeding localities for the Snowy Plover in western Mexico. Western Birds 36: 141-143.

Mellink, E. \& M.E. Riojas-López. 2006. Nesting of Forster's Tern in a tropical coastal lagoon (Cuyutlán, Colima) in southern Mexico. Western Birds 37: 45-47.

Mellink, E., J. Luévano \& I. Zuria. 1998. Nota sobre los pelecaniformes, ciconiiformes, gallitos marinos (Sterninae) y rayadores (Rynchopinae) de la Costa Chica de Oaxaca, México. Ciencias Marinas 24: 367-388.

Mellink, E., E. Palacios y E. Amador. 2007. Colonies of Four Species of Terns and the Black Skimmer in Western México. Waterbirds 30: 358-366.

Palacios, E. y E. Mellink. 2007. The colonies of vanRossem's Gull-billed Tern (Gelochelidon nilotica vanrossemi) in México. Waterbirds 30: 214-222.

Robinson, J.A., J.M. Reed, J.P. Skorupa \& L.W. Oring. 1999. Black-necked Stilt, p. 449. In A. Poole \& F. Gill (eds.) The Birds of North America. Acad. Nat. Sci., Philadelphia, Pennsylvania, USA.

Schaldach, W.J. 1963. The avifauna of Colima and adjacent Jalisco, Mexico. Proc. West. Found. Vert. Zool. 1: 1-100.

Schaldach, W.J. 1969. Further Notes on the avifauna of Colima and adjacent Jalisco, México. An. Inst. Biol. UNAM 40: 299-316. 
